\title{
Aktualisasi Perkunjungan Pastoral Menurut 1 Petrus 5:1-3 Terhadap Pertumbuhan Iman Jemaat GPI Bt. Aji
}

\author{
Rita Evimalinda ${ }^{1 *}$ Eko Prasetyo $^{2}$, Agustinus Sihombing ${ }^{3}$, Vicky Baldwin \\ Goldsmith Dotulong Paat ${ }^{4}$ \\ ${ }^{1}$ Prodi Studi PAK, STT Real Batam \\ ${ }^{2,3,4}$ Prodi Studi Teologi, STT Real Batam \\ ritaevimalinda76@gmail.com
}

\begin{abstract}
Pastoring the church is a noble calling from the Lord Jesus Christ as the owner of the sheep, which of course is done with full responsibility and selfdedication. However, lately negative issues of some church leaders have gone viral on social media related to luxury, sexual scandals, corruption, the church being used as a business field. This of course spoils the image of a proper shepherd. The main focus of this article is to explain the Poimaino Concept in 1 Peter 5:1-3 which will be an indicator in actualizing church pastoralism, namely: a shepherd is in charge of guiding, caring for, feeding, managing and caring for God's flock. The five indicators are a unity in carrying out pastoral duties, and Jesus Christ has become the prototype of all pastors.
\end{abstract}

Keywords: Actualization, Pastoring, Church, Pastor

\begin{abstract}
Abstrak
Penggembalaan adalah panggilan mulia dari Tuhan Yesus Kristus sebagai pemilik domba, yang tentunya dikerjakan dengan penuh tanggung jawab serta pengabdian diri. Namun, belakangan isu-isu negatif beberapa pemimpin gereja banyak viral di media sosial terkait akan kemewahan, skandal seksual, korupsi, gereja dijadikan ladang bisnis. Hal ini tentu saja merusak citra gembala semestinya. Fokus utama artikel ini adalah menjelaskan Konsep Poimaino pada 1 Petrus 5 :1-3 yang akan menjadi indikator dalam mengaktualisasi pengembalaan gereja yaitu: seorang gembala bertugas membimbing, merawat, memberi makan, mengatur dan memelihara kawanan domba Allah. Kelima indikator itu merupakan satu kesatuan dalam sepanjang menjalankan tugas pastoral, dan Yesus Kristus telah menjadi prototype dari seluruh gembala.

Kata Kunci: Aktualisasi, Penggembalaan, Gereja, Pendeta,
\end{abstract}




\section{PENDAHULUAN}

Kepemimpinan seorang gembala sangat mempengaruhi pelayanan dan perkembangan gereja. Namun fakta yang tidak bisa dibantah masih banyak ditemukan perilaku-perilaku yang menyimpang dari pemimpin gereja sehingga fungsi pastoral tidak berfungsi dengan baik dan maksimal yang mengakibatkan terjadinya konflik dalam gereja bahkan tidak sedikit berujung pada kematian. Gereja yang seharusnya memiliki standar moral yang tinggi, yang tidak dimiliki organisasi duniawi pada umumnya, namun dalam kenyataanya sering didapati perilaku penyimpangan dalam gereja baik oleh oknum pribadi maupun organisasi gereja. Situs media massa online https:/www.bbc.com/indonesia/dunia melaporkan di Chili lebih dari 100 rohaniawan gereja tengah diselidiki atas dugaan kejahatan seksual yang menggiring gereja terjerembab kedalam krisis (tahun 2018). Bentuk skandal lain, penelitian yang di lakukan Kristanto memperlihatkan korupsi rata-rata terjadi pada gereja besar baik dari segi organisasi, jumlah jemaat maupun jumlah persembahan yang terkumpul, kasus korupsi tampak dipermukaan seperti fenomena gunung es. ${ }^{1}$ Fenomena demi fenomena tersebut menjelaskan bahwa permasalahan yang substansi pada kepemimpinan gembala bukanlah sebatas seorang gembala melakukan praktek kepemimpinan atau tidak, tetapi bagamaina menjadi individu seutuhnya yang being, thinking,doing adalah pemimpin ${ }^{2}$. Sebagaimana penelitian yang berkaitan dengan tema ini adalah penelitian Kosta dan Djadi ${ }^{3}$ menjelaskan seorang gembala sebagai pemimpin memiliki peran memberi nasihat, melayani dengan kerelaan, bertanggung jawab, dan hendaknya memberi teladan. Dan Rupa menambahkan indikator kerendahan hati sebagai ciri khas yang harus dimiliki seorang gembala sidang. ${ }^{4}$ Dengan mempertimbangkan kedua pembahasan tersebut ada hal yang belum menjadi sebuah pembahasan dan pengembangan dalam kedua artikel tersebut, yakni

1 Eka Adhi Wibowo dan Heru Kristanto, "Korupsi Dalam Pelayanan Gereja: Analisis Potensi Penyimpangan Dan Pengendalian Internal," Universitas Kristen Duta Wacana
ttps://jurnal.kpk.go.id/index.php/integritas/article/download/104/5/.

${ }^{2}$ Ivan Th.J Weismann \& Nicodemus Yuliastomo, "Kepemimpinan Gembala:Suatu Kajian Filosofis Tentang Proses Integrasi Kepemimpinan Rohani Dan Sekuler," , https://media.neliti.com/.../137819-kepemimpinan-gembala-suatu-kajian- filoso2330ae3f.pdf.

3 Katarina \& Krido Siswanto, "Keteladanan Dan Kepemimpinan Yesus Dan Implikasinya Bagi Kepemimpinan Gereja Masa Kini," Sekolah Tinggi Teologi Simpson Vol 2 (2018), https://journal.sttsimpson.ac.id/index.php/EJTI/article/download/102/pdf.

${ }^{4}$ Calvin Sholla Rupa, "CIRI KHAS SEORANG GEMBALA BERDASARKAN PERSPEKTIF 1 PETRUS 5:1-4," n.d., ojs.sttjaffray.ac.id/. 
konsep paimaino menurut 1 pet 5:1-5 yang diaktualisasikan dalam pengembalaan. Yang diharapkan dapat memberi sumbangsih pemikiran bagi penggembalaan jemaat di gereja.

\section{METODE}

Penelitian dilakukan dengan studi literatur khususnya untuk memaparkan konsep-konsep utama dan definitif tentang poin-poin penting pastoral menurut perspektif 1 petrus 5:1-4. Pembahasan dimulai dengan eksageses ayat 1 sampai ayat 4 dan ditutup dengan bagaimana konsep Paimano menurut 1 petrus 5:1-4. Hasil yang diharapkan adalah penjelasan deskriptif, sistematis dan analitik tentang bagaimana Konsep Paimano dalam aktualisasi Penggembalaan Gereja menurut 1 Petrus 5:1-4

\section{HASIL DAN PEMBAHASAN}

Tafsiran Matius 19:6

Matius Kata gembala kerap kali muncul dalam Alkitab, karena beternak adalah mata pencarian yang banyak dilakukan di Israel bahkan tokoh-tokoh Alkitab seperti Abraham, Musa, Daud adalah juga seorang gembala. Di dalam Kamus Besar Bahasa Indonesia dijelaskan yang dimaksud dengan kata "gembala" adalah sebagai penjaga atau pemelihara mahluk hidup. Howard Rice kata "Gembala dalam bahasa latin ialah pastor dan dalam bahasa Indonesia diterjemahkan pendeta sebagai Pengayom, pemimpin dan pembina ${ }^{5}$. Seorang menjadi gembala karena ia dipilih Allah dan dipercayakan oleh jemaat untuk menjadi gembala dan seorang yang sungguh-sungguh mengasihi Tuhan bukan memilih jabatannya tetapi dipilih untuk jabatannya ${ }^{6}$. Pada gereja mula-mula jabatan ini disebut penatua, posisi yang agung yakni pelayan dan gembala warga jemaat, yang bertanggungjawab terhadap seluruh bentuk pelayanan gerejawi ${ }^{7}$ Sehingga jemaat mula-mula memberikan penghargaan kepada gembala jemaat yang dianggap bijaksana dan diharapkan memberikan contoh yang baik. Pandangan ini masih terus dilanjutkan oleh beberapa gereja masa kini.

Sedangkan istilah pengembalaan terutama digunakan dalam gerejagereja Indonesia, sama dengan ungkapan 'pelayanan' ${ }^{8}$ Kata

\footnotetext{
2006).hal.19

${ }^{6}$ Robert Cowls, Gembala Sidang (Bandung: Kalam Hidup, n.d.).hal. 7

7 "Kristanto, A. (1993). Memahami Amanat Penggembalaan Dalam Surat Petrus
}

5 Howard Rice, Manajemen Umat (Terjemahan) (Bandung: Kalam Hidup, 5:1-4. (Undergraduate Thesis, Duta Wacana Christian University, 1993). Retrieved from Http://Sinta.Ukdw.Ac.Id".

${ }^{8}$ Johannes Ludwig Chrysostomus Abineno, Pedoman Praktis Untuk Pelayanan Pastoral (Jakarta: BPK Gunung Mulia, 2010).hal. 9 
"gembalakanlah" diambil dari kata poimaino. Dalam situs online (https://alkitab.sabda.org) transliterasi: poimainó, asal kata: Dari kata poimen; cenderung sebagai gembala (kiasan, pembimbing). penggunaan: memberi makan (ternak). diterjemahkan sebagai penggembalaan, maka kata "gembalakanlah" menggunakan istilah poimaino yang berarti membimbing dalam memberi makan, merawat, mengatur dan memelihara domba-domba. Jadi pengembalaan adalah segala sesuatu yang berhubungan dengan tugas seorang gembala.

Konteks Dalam 1 Petrus 5:1, nasehatnya ditujukan kepada para panatua pada waktu itu, pengurus gereja hidup sesuai kehendak Tuhan. Petrus menempatkan diri sebagai sahabat bagi penatua yang ada dan saksi penderitaan kristus. Kata Yunani diterjemahkan menjadi "Saksi" dalam bahasa inggris martyr (syahid). Oleh karenanya Petrus menasihati teman penatuanya, para pelayan jemaat-jemaat yang ditulisi pada surat ini, agar menunaikan tugas pengajaran dengan baik. Kata "menasihati" dalam Yunani

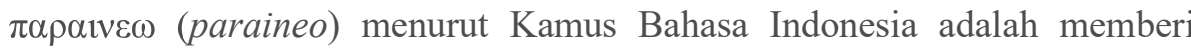
ajaran atau pelajaran baik; sedangkan nasihat adalah anjuran (petunjuk, peringatan, teguran) yang baik, berkaitan dengan hal ini maka gembala, pemimpin gereja, para majelis, pendeta, dan para pembimbing rohani, para penatua, yang pekerjaannya mengajari orang lain harus benar-benar mengindahkan dan setia melakukan tugas mereka sendiri. Petrus menekankan bahwa kesetiaan dalam menjalankan tugas dari jabatan penatua adalah sangat penting dalam masa-masa menghadapi tantangan, penganiayaan, hambatan, dan penderitaan jemaat kala itu ${ }^{9}$ Sehingga pelayan dan orang Kristen sejati akan mendapat bagian dalam kemuliaan yang akan dinyatakan kelak pada hari kedatangan Kristus.

Dalam 1 Petrus 5: 2 kata "gembalakanlah" menggunakan istilah poimaino yang berarti membimbing dalam memberi makan, merawat, mengatur dan memelihara domba-domba. Yang merupakan kawanan domba Allah, adapun indikator penggembalaan yang terdapat pada ayat 2 yaitu:

\section{Membimbing kawanan domba Allah}

Domba adalah binatang yang lemah. Domba tidak memiliki alat pertahanan diri yang dapat melindungi dirinya sendiri dari bahaya yang yang mengancamnya. Oleh karena itu domba membutuhkan gembala yang bukan saja mampu memberikan makanan kebutuhannya, melainkan gembala yang

9 Yenda Kosta and Jermia Djadi, "Peranan Gembala Sebagai Pemimpin Dalam Perspektif I Petrus 5:1-4 Dan Relevansinya Pada Masa Kini," Jurnal Jaffray 9, no. 2 (October 2, 2011): 172, https://doi.org/10.25278/jj71.v9i2.100. 
juga mampu membimbing domba kepada keselamatan hidupannya. Dalam nyanyian Daud Mazmur 23 dituliskan "Ia membimbingku ke air yang tenang", ini sebenarnya suatu contoh nyata Tuhan berikan kepada para gembala yang mana Allah adalah gembala yang baik, yang sanggup membimbing umat-Nya untuk dapat menemukan kehidupan yang baik. Jika kembali pada pokok bahasan ini yang mana gembala adalah seorang pembimbing, Pemimpin yang membimbing jemaat dapat memberi Konseling atau bimbingan sebagai bagian yang penting dari pelayanan pastoral. Setiap orang percaya mempunyai masalah, baik orang dewasa, pemuda maupun anak-anak, masalah pribadi, masalah keluarga, masalah pekerjaan dan sebagainya. Sebab itu, bimbingan sangat perlu dalam penggembalaan jemaat. Bimbingan harus dilakukan berdasarkan firman Tuhan sehingga Jemaat dapat mengungkapkan segala permasalahan yang sedang dihadapinya secara terus terang atau terbuka untuk diselesaikan secara tuntas di hadapan Tuhan ${ }^{10}$. dengan memberikan firman Allah yang murni, dan memimpin mereka sesuai dengan arahan dan aturan yang ditetapkan firman Allah, menganggap umat sebagai pusaka Allah, dan memperlakukan mereka dengan selayaknya. Dalam melakukan konseling seorang gembala menerapkan etika konseling sehingga tidak terjebak kedalam perlakuan yang tidak terpuji, misalnya gembala tidak sendirian tetapi menggandeng konselor lain mewakili gender pria dan wanita. Bentuk lain membimbing adalah seorang gembala memastikan para kawanan domba Allah agar tidak jatuh dan terhindar dari serigala yang ganas yakni nabi-nabi palsu (kisah para rasul 20:29), yang datang dari luar dan merealisasikan dirinya diantara kawanan domba Allah, untuk menyesatkan orang percaya. Jemaat harus dibimbing agar dapat memiliki kepekaan apakah pengajaran itu benar atau tidak.

\section{Memberi makan kawanan domba Allah}

Seorang gembala jemaat bukan hanya dapat memenuhi kebutuhan spiritual atau batiniah tetapi juga kebutuhan lainnya. Daud menuliskan dalam kitab mazmur Gembala yang baik akan memberi makan kawanan dombanya untuk kelangsungan hidup, membawa domba ke padang rumput yang hijau (maz 23:1-2). Manusia membutuhkan makanan untuk tubuh jasmani dan tubuh batiniah atau rohaninya. Dalam hal memenuhi kebutuhan rohani atau batiniah, jemaat membutuhkan firman Allah yang murni yang akan menjadi konsumsi dan vitamin makanan batiniah untuk pertumbuhan rohani jemaat. Gembala bertanggung jawab memberi nutrisi makanan terbaik untuk batiniah 2005).hal.44

${ }^{10}$ Jermia Djadi, Teologi Pastoral (Makassar: Sekolah Tinggi Theologia Jaffray, 
seperti yang Allah kehendaki. Sehingga pikiran, perasaan dan kehendak jemaat Tuhan akan semakin sama seperti Kristus. Dalam memberi makan jasmani, seorang gembala sesuai dengan kemampuan akan menolong orangorang yang tidak mampu, tidak mementingkan diri sendiri. Hal yang sama dilakukan Yesus dalam pelayanannya dengan memberi makan 5000 orang laki-laki dewasa tidak termasuk perempuan dan anak-anak, kerumunan massa yang berbondong-bondong untuk mendengar pengajaran Yesus. Keletihan dan banyaknya rintangan dalam perjalanan membuat hati Tuhan iba dan tidak ingin massa pulang dengan kecewa. Namun ironisnya, Penelitian Katarina dan Siswanto menyimpulkan kepemimpinan gereja masa kini cenderung pada ambisi pribadi, memanfaatkan kekuasaan dan mencari keuntungan diri sendiri, hidup dalam kemewahan. ${ }^{11}$ bahkan objektifitas gembala menjadi hilang karena takut kehilangan sumber-sumber pendapatan dari jemaat yang kaya raya ${ }^{12}$

\section{Merawat kawanan domba Allah}

Pekerjaan merawat kawanan domba bukanlah perkara mudah. Merawat artinya menjaga, mengurus, melatih (berjalan), membela (orang sakit) ${ }^{13}$. Ini adalah suatu bentuk pelayanan yang membutuhkan hati yang penuh dengan cinta dan kasih sayang terhadap domba-dombanya. Perawatan seperti mengobati yang luka atau menyembuhkan yang sakit, membersihkan dari kotoran-kotoran, membuat tempat tinggal kawanan domba menjadi lebih nyaman dan aman dan lain sebagainya. Ini semua adalah suatu gambaran atau kiasan yang harus dikerjakan oleh seorang gembala terhadap jemaat yang Tuhan percayakan, jika ada anggota jemaat yang jatuh ke dalam dosa, dibina agar mereka jangan berbuat dosa lagi. Gembala jemaat bertanggung jawab atas jiwa jemaat Tuhan, dibawa kembali ke jalan yang benar dalam roh yang lemah lembut dan belas kasihan (Galatia 6:1). Wujud lain dalam konteks pemeliharaan kawanan domba jemaat Allah adalah dengan terjun langsung ke lapangan untuk melihat kondisi kesehatan dari dombadombanya. White memaparkan seorang Gembala sebagai pelayan injil rajin mengunjungi dari rumah ke rumah jemaat, menyembuhkan orang sakit, menghibur yang berdukacita, membicarakan damai sejahtera kepada yang bersedih. Menggendong anak-anak kecil dan memberkati mereka,

11 Siswanto, "Keteladanan Dan Kepemimpinan Yesus Dan Implikasinya Bagi Kepemimpinan Gereja Masa Kini."

"Pendeta Dan Kekayaan," 2019,
https://www.kompasiana.com/drumielnugroz/5cfdc90e0d8230514d6872c8/pendeta-dankekayaan.

${ }^{13}$ https://Kbbi.Kemdikbud.go.id/. 
mengucapkan kata-kata pengharapan dan penghiburan bagi jemaat yang berduka atau sedang mengalami permasalahan. ${ }^{14}$

\section{Mengatur kawanan domba Allah - Manager}

Dalam hal ini seorang Gembala menjalankan fungsi manajerial, sebagai pemimpin yang mampu mengatur setiap anggota jemaat agar tetap aman dan nyaman dalam satu wadah yang sama yakni gereja dimana mereka dilayani. Dalam tulisannya Fredy simanjuntak menjelaskan penggembalaan memiliki dimensi kepemimpinan, sebaliknya poses kepemimpinan belum tentu merupakan bagian dari sebuah penggembalaan. ${ }^{15}$ Kurang menegaskan penelitiannya, seorang gembala adalah pimpinan gereja yang menjalankan fungsi kepemimpinan selaku penilik dan pengatur. Membuat tujuan bersama sesuai kehendak Allah dan memastikan tiap anggota jemaat termotivasi untuk mencapai tujuan atau visi yang telah ditetapkan untuk dicapai. ${ }^{16}$ Yesus Kristus adalah sang gembala agung yang patut diteladani oleh seluruh gembala jemaat yang dalam kepemimpinanya selalu menularkan visi dan misi sehingga seluruh murid dan pendengarnya dapat dipengaruhi oleh perkataan dan perbuatanNya bukan otoriter ${ }^{17}$. Petrus tidak menyatakan diri memiliki kedaulatan atas seluruh penatua dan jemaat, juga tidak berlagak sebagai pemimpin para rasul atau kepala jemaat, tetapi menilai dirinya sendiri sebagai seorang penatua, saudara sesama majelis atau rekan penatua. Jadi sama seperti yang dilakukan Yesus cara terbaik yang dapat dilakukan seorang pendeta atau gembala jemaat untuk dapat dihormati oleh jemaatnya ialah dengan melaksanakan tugas dengan sebaik-baiknya, dan dengan terusmenerus menjadi contoh bagi mereka dalam segala hal yang baik, sehingga isu negatif tentang gereja berkurang. Para pemimpin gereja atau pendeta yang melaksanakan pekerjaan pelayanannya karena terdesak oleh kebutuhan atau tertarik untuk melakukan itu karena uang, tidak akan pernah bisa melakukan kewajibannya sebagaimana seharusnya, sebab tidak melakukannya dengan sukarela dan dengan pengabdian diri. Seorang pemimpin juga harus mampu melatih dan menuntun anggotanya agar dapat mengerjakan tugas yang telah dipercayakan kepadanya, sehingga dapat

${ }^{14}$ Ellen G. White, Pelayan Injil (Bandung: Indonesia Publishing House, 1995). Hal.166

${ }^{15}$ Fredy Simanjuntak and Yudhy Sanjaya, "Amanat Penggembalaan Dalam Ruang Virtual," Thronos 1, no. 2 (2020): 99-114.

${ }^{16}$ Sadrak Kurang, "Dimensi Pelayanan Pastoral," Jurnal Jaffray 2, no. 2 (April 2, 2005): 1, https://doi.org/10.25278/jj71.v2i2.155.

17 Siswanto, "Keteladanan Dan Kepemimpinan Yesus Dan Implikasinya Bagi Kepemimpinan Gereja Masa Kini." 
menghasilkan pemimpin - pemimpin masa depan. Kesimpulan yang dapat diambil dari fenomena-fenomena diatas, seorang yang dalam menjalankan penggembalaan sebagai pemimpin dalam mengatur kawanan domba Allah memiliki visi, bersikap sebagai kawan sekerja Allah, dan melakukan tugas dengan penuh pengabdian diri, serta dapat menghasilkan pemimpin yang baru.

\section{Memelihara kawanan domba Allah}

Memelihara artinya menyelamatkan; melindungi; melepaskan (meluputkan) dari bahaya dan sebagainya ${ }^{18}$. Agar kawanan domba Allah atau jemaat dapat tumbuh dan berkembang biak dengan baik dibutuhkan pemeliharaan oleh gembala. Dunnam, Prioritas seorang gembala yang baik bukan hanya mengenal tetapi juga memelihara miliknya ${ }^{19}$ berbagai aktifitas keagamaan untuk menguatkan spiritualitas dilakukan misalnya seminar keluarga, kalangan pemuda maupun anak-anak. Mengadakan kelas pendalaman Alkitab sesuai tingkat usia, membentuk kelompok diskusi (cell group) untuk perkembangan spiritual baik individu maupun kelompok bersama. Selanjutnya Barclay menambahkan Gembala itu secara pribadi bertanggung jawab bagi domba-dombanya. Gembala itu adalah ahli mencari jejak domba yang hilang. ${ }^{20}$ Acapkali gembala tidak mengenal dombanya sehingga yang tidak pernah muncul dalam persekutuan pun tidak diketahui atau dibiarkan. Paulus dan Barnabas dalam penginjilannya tidak menghiraukan aniaya dan bahaya yang dihadapi saat memberitakan injil dalam mengunjungi beberapa daerah atau jemaat. Hal ini dilakukan adalah untuk memelihara kawanan domba yang sudah diperoleh dengan darah Kristus dan karya Roh Kudus terhindar dari ajaran yang sesat dan ketidakpercayaan yang berkembang saat itu, tetapi agar jemaat dan para pelayan bertekun dalam iman. (Kisah Rasul 14:21-28).

Sisi lain, Ourtlund menuliskan dalam bukunya yang berjudul 'Filsafat Pelayanan Berdasarkan Alkitab' dan dikutib sebuah artikel Kristen bahwa gereja lokal yang sehat memiliki kesadaran sosial. Di lingkungan gereja, dijumpai banyak orang yang miskin, sakit di rumah atau rumah sakit, orang yang di penjara dan orang yang menderita karena berbagai masalah kehidupan. Gembala harus melatih anggota-angota jemaatnya untuk berperan

\footnotetext{
${ }^{18}$ https://kbbi.kemdikbud.go.id/ n.d.

${ }^{19}$ Dunnam Maxie, Akulah....Studi Mengenai Tujuh Pernyataan Yesus (Jakarta: BPK Gunung Mulia, 2001).hal.21

${ }^{20}$ William Barclay, Pemahaman Alkitab Setiap Hari Injil Lukas (Jakarta: BPK Gunung Mulia, 2008).293
} 
dalam tugas pelayanan khusus dan Gembala dapat mengarahkan perhatian gereja untuk mengatasi berbagai permasalahan sosial yang timbul di daerah di mana gereja berada. ${ }^{21}$

\section{KESIMPULAN}

Jika Tuhan dan jemaat mempercayakan jabatan kepemimpinan di gereja, seorang gembala akan mempertanggungjawabkan pengembalaannya kepada Tuhan. Konsep Poimoino dapat menjadi indikator dalam mengaktualisasi penggembalaan gereja menurut 1 Petrus 5:1-3 yaitu: (1) Seorang gembala membimbing kawanan domba Allah untuk keselamatan hidupnya dan mendapatkan kehidupan yang lebih baik, (2) Seorang Gembala memberi makan rohani dan jasmani kawanan domba Allah untuk kelangsungan hidup spiritual dan jasmani jemaat, (3) Seorang Gembala merawat kawanan domba Allah yang dipercayakan dengan penuh cinta kasih sehingga merasa aman dan nyaman dalam wadah gereja dimana dilayani. (4) Seorang Gembala mengatur kawanan domba Allah dalam merencanakan visi dan misi gereja dan memotivasi jemaat untuk bersama-sama menjalankannya agar tercapai, (5) Seorang Gembala harus memelihara kawanan domba yang telah dipercayakan agar tidak tersesat dan hilang jiwanya

Disamping konsep Poimaino diaktualisasikan dalam penggembalaan, yang tidak kalah pentingnya adalah karakteristik seorang Gembala dalam mengerjakan seluruh tugas penggembalaan yaitu dengan penuh pengabdian diri, dan menjadi teladan bagi jemaatnya dalam perkataan, tingkahlaku, kasih, kesetiaan, dan kesucian.

\section{KEPUSTAKAAN}

$$
\text { "Pendeta Dan Kekayaan," } 2019 .
$$

https://www.kompasiana.com/drumielnugroz/5cfdc90e0d8230514d6872c8/p endeta-dan-kekayaan.

Abineno, Johannes Ludwig Chrysostomus. Pedoman Praktis Untuk Pelayanan Pastoral. Jakarta: BPK Gunung Mulia, 2010.

Barclay, William. Pemahaman Alkitab Setiap Hari Injil Lukas. Jakarta: BPK Gunung Mulia, 2008.

Cowls, Robert. Gembala Sidang. Bandung: Kalam Hidup, n.d.

Djadi, Jermia. Teologi Pastoral. Makassar: Sekolah Tinggi

Theologia Jaffray, 2005.

\footnotetext{
${ }^{21}$ e-Jimmy, "Lima Cara Gereja Lokal Dapat Bertumbuh Secara Sehat," n.d., https://misi.sabda.org/.
} 
e-Jimmy. "Lima Cara Gereja Lokal Dapat Bertumbuh Secara Sehat," n.d. https://misi.sabda.org/.

https://Kbbi.Kemdikbud.Go.Id/," n.d.

Kosta, Yenda, and Jermia Djadi. "Peranan Gembala Sebagai

Pemimpin Dalam Perspektif I Petrus 5:1-4 Dan Relevansinya Pada Masa

Kini." Jurnal Jaffray 9, no. 2 (October 2, 2011): 172.

https://doi.org/10.25278/jj71.v9i2.100.

"Kristanto, A. (1993). Memahami Amanat Penggembalaan Dalam Surat Petrus 5:1-4. (Undergraduate Thesis, Duta Wacana Christian University, 1993). Retrieved from Http://Sinta.Ukdw.Ac.Id," n.d.

Kristanto, Eka Adhi Wibowo dan Heru. "Korupsi Dalam Pelayanan Gereja: Analisis Potensi Penyimpangan Dan Pengendalian Internal."

Universitas Kristen Duta Wacana Volume 3 N (2017).

ttps://jurnal.kpk.go.id/index.php/integritas/article/download/104/5/.

Kurang, Sadrak. "Dimensi Pelayanan Pastoral." Jurnal Jaffray 2, no. 2 (April 2, 2005): 1. https://doi.org/10.25278/jj71.v2i2.155.

Maxie, Dunnam. Akulah....Studi Mengenai Tujuh Pernyataan Yesus. Jakarta: BPK Gunung Mulia, 2001.

Nicodemus Yuliastomo, Ivan Th.J Weismann. "Kepemimpinan Gembala:Suatu Kajian Filosofis Tentang Proses Integrasi Kepemimpinan Rohani Dan Sekuler," n.d. https://media.neliti.com/.../137819kepemimpinan-gembala-suatu-kajian- filoso-2330ae3f.pdf.

Rice, Howard. Manajemen Umat (Terjemahan). Bandung: Kalam Hidup, 2006.

Rupa, Calvin Sholla. "CIRI KHAS SEORANG GEMBALA BERDASARKAN PERSPEKTIF 1 PETRUS 5:1-4,” n.d. ojs.sttjaffray.ac.id/.

Siswanto, Katarina \& Krido. "Keteladanan Dan Kepemimpinan Yesus Dan Implikasinya Bagi Kepemimpinan Gereja Masa Kini.” Sekolah Tinggi Teologi Simpson Vol 2 (2018).

https://journal.sttsimpson.ac.id/index.php/EJTI/article/download/102/pdf. Simanjuntak, Fredy, and Yudhy Sanjaya. "Amanat Penggembalaan

Dalam Ruang Virtual.” Thronos 1, no. 2 (2020): 99-114. White, Ellen G. Pelayan Injil. Bandung: Indonesia Publishing House, 1995. 